\title{
Effects of watershed and riparian zone characteristics on nutrient concentrations in the River Scheldt Basin
}

\author{
J. Meynendonckx ${ }^{1}$, G. Heuvelmans ${ }^{2}$, B. Muys ${ }^{3}$, and J. Feyen ${ }^{3}$ \\ ${ }^{1}$ Flemish Institute for Technological Research, Boeretang 200, 2400 Mol, Belgium \\ ${ }^{2}$ Ecorem consultants nv, Kontichsesteenweg 38, 2630 Aartselaar, Belgium \\ ${ }^{3}$ Department of Land Management and Economics, Faculty of Bioscience Engineering, Katholieke Universiteit Leuven, Vital \\ Decosterstraat 102, 3000 Leuven, Belgium
}

Received: 10 January 2006 - Published in Hydrol. Earth Syst. Sci. Discuss.: 2 May 2006

Revised: 8 November 2006 - Accepted: 23 November 2006 - Published: 28 November 2006

\begin{abstract}
The relative influence of a set of watershed characteristics on surface water nutrient concentrations was examined in 173 watersheds within two subcatchments (UpperScheldt and Nete) of the River Scheldt Basin (Flanders, Belgium). Each watershed was described by seasonal rainfall, discharge loading of point sources, morphological characteristics (area, average slope, drainage density, elongation), land use and soil properties (soil texture and drainage). Partial regression analysis revealed that soil drainage variables had the strongest influence on nutrient concentrations. Additional influence was exerted by land use and point source loading variables. Nitrate concentrations were positively correlated with effluent loadings coming from wastewater treatment plants and with the area of agricultural land. Phosphate concentrations were best explained by effluent loadings of industrial point sources and by the area of urban land. Land use close to the river was not a better predictor of nitrate and phosphate concentrations than land use away from the river. This suggests that the mediating impact of riparian zones is rather explained by the hydrologic pathways within the buffer strip.
\end{abstract}

\section{Introduction}

Eutrophication is one of the most important threats to surface water quality and river ecosystems. A main issue facing watershed planners is how land use and management ties to the quality at the river basin outlet. The past decades, several researchers tried to relate water quality variables to land management using empirical techniques like correlation and regression analysis, often embedded in a GIS environment (Hill, 1978; Wilkin and Jackson, 1983; Osborne and Wiley, 1988; Hunsaker and Levine, 1995; Bolstad and Swank,

Correspondence to: J. Feyen

(jan.feyen@biw.kuleuven.be)
1997; Tufford et al., 1998; Norton and Fisher, 2000; Sliva and Williams, 2001; Davis and Neal, 2004).

Surface waters are contaminated by human activities in two ways: (1) by point sources, such as the effluent of industries and wastewater treatment plants (WTP's), and (2) by diffuse sources, such as the runoff from urban and agricultural areas. The importance of point sources for water quality depends on the extent of industrial activity and urban land with respect to the basin area under agriculture and forest and the level and efficiency of pre-discharge treatment processes (Ometo et al., 2000). Diffuse sources are more difficult to monitor because nutrients follow a variety of pathways depending on the hydrological routing between overland, subsurface and base flow (Haycock et al., 1993; Nikolaidis et al., 1998; Dzikiewicz, 2000). Different flow components dominate $\mathrm{N}$ and $\mathrm{P}$ concentrations and export. Most of the $\mathrm{N}$ is exported from watersheds as nitrate through subsurface flow and is therefore diffuse in space and time. In contrast, $\mathrm{P}$ export, whether associated to sediments or the water phase, usually occurs from critical source areas because $\mathrm{P}$ is mainly transported by overland flow from near stream areas during storm periods (Soranno et al., 1996; Pionke et al., 2000).

One landscape element which can exert a moderate to strong mediating effect on nutrient export is the land-water ecotone, i.e. the riparian zone. This zone is considered important with respect to the regulation of the transport of sediments, water and nutrients across the landscape, and has been subject of research and target of management and restoration efforts (Omernik et al., 1981; Lowrance et al., 1984; Peterjohn and Correll, 1984; Mulholland, 1992; Haycock et al., 1993; Hill, 1996; Johnson et al., 1997; Tufford et al., 1998). Despite the well-known functions of riparian zones in moderating stream nutrient concentrations (e.g. review of Haag and Kaupenjohann, 2001), the relative influence of riparian zone versus the whole watershed characteristics on ambient nutrient concentrations is poorly understood. Several researchers found that land use adjacent to the stream was not a better

Published by Copernicus GmbH on behalf of the European Geosciences Union. 


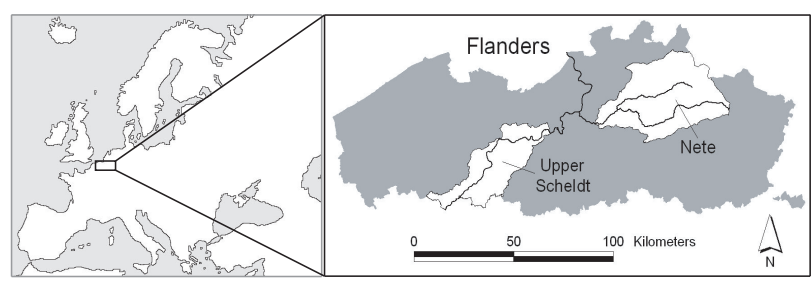

Fig. 1. Location of the study area.

predictor of nutrient concentrations than land use composition of the whole watershed (Omernik et al., 1981; Johnson et al., 1997; Sliva and Williams, 2001). These results are in contrast to reports citing the opposite (Richards et al., 1996; Tufford et al., 1998) and to reports citing the benefits of riparian vegetation in reducing sediment and nutrient inputs to streams (e.g. Dillaha et al., 1989; Osborne and Kovacic, 1993; Fennessy and Cronk, 1997).

This paper describes the results of a study investigating the effects of watershed and riparian zone characteristics on the surface water nitrate and phosphate concentrations in the River Scheldt Basin. Thereto, two subcatchments were selected representing different conditions in the study basin. The spatial variability in observed nitrate and phosphate concentrations within these subcatchments was related to a variety of watershed characteristics. The role of point and diffuse sources, anthropogenic (e.g. land use) and natural watershed characteristics (e.g. geomorphic characteristics and soil properties), and the time and spatial dependent precipitation variable were taken into consideration. With respect to watershed characteristics the following three research questions were addressed:

1. What is the relationship between watershed characteristics and surface water quality?

2. Is this relationship seasonal?

3. Do land use and soil properties near the stream better describe the variability in nitrate and phosphate concentrations than land use and soil properties in the whole watershed?

\section{Method}

\subsection{Study area}

The study area consists of two subcatchments of the River Scheldt Basin situated in one of the most densely populated and intensively managed regions of northwest Europe (Fig. 1). The climate is classified as marine, temperate, with an average annual precipitation of $800 \mathrm{~mm}$. The UpperScheldt subcatchment, covering $946 \mathrm{~km}^{2}$, is situated in the Flemish hill district where the geologic substrate consists of discontinuous quaternary layers of loamy sand and sandy loam on tertiary sands and clays. Most soils are well to mod- erately drained loam and sandy loam soils. Elevations range from 3 to $150 \mathrm{~m}$ above sea level. Land use is dominated by arable land (cropland $46 \%$ and pasture $29 \%$ of the area), with crop acreage dominated by wheat, corn, potatoes and sugar beets. The region is poorly seweraged with only one third of the households connected to a sewer system. The Nete subcatchment, $1673 \mathrm{~km}^{2}$ in size, is situated in the Central Kempen where the geologic substrate consists of quaternary sands on tertiary sands and clays. The watershed has a fairly uniform topography with elevations ranging from 2 to $68 \mathrm{~m}$ above sea level. Most soils are moderately to poorly drained sands and loamy sands. The dominant land use categories are forests, followed by field crops and pasture, respectively $30 \%, 29 \%$ and $16 \%$ of the area. The Nete catchment is slightly more urbanized than the Upper-Scheldt catchment (19\% versus $16 \%$ ) and more households are connected to a sewer of which the water is treated before discharged in the river system (63\% versus 35\%). In both catchments, industrial activities such as chemistry, food, textile and metal industries contribute to the $\mathrm{N}$ and $\mathrm{P}$ loading of the rivers.

\subsection{Data sources and data (pre-)processing}

\subsubsection{Water chemistry}

Water quality data were obtained from the Flemish Environment Agency, which takes and analyses samples of surface waters in Flanders (VMM, 2002). During the years 19982001 , the nitrate $\left(\mathrm{NO}^{3-}\right)$ and phosphate $\left(\mathrm{PO}^{3-}\right)$ concentrations were determined at 67 sampling sites in the UpperScheldt catchment and at 106 sampling sites in the Nete catchment. Because of the low sampling frequency (one observation per month) the dataset does not permit a detailed analysis of the temporal variation in water quality. Calculating nutrient loadings could reduce the temporal variability, but this was impossible because river discharge data are not monitored at the same locations as the water quality, nor is the sampling frequency the same. In order to reduce the impact of variations in discharge, nitrate and phosphate concentrations were averaged by season: winter (DecemberFebruary), spring (March-May), summer (June-August) and fall (September-November). As a consequence the derivation of the relationship between nitrate and phosphate concentrations and the watershed characteristics in this study was based on the seasonal average nutrient concentration.

\subsubsection{Watershed characteristics}

A vector-based geographic database was compiled for the Upper-Scheldt and Nete catchments. Each database included layers on topography, streams, water quality monitoring sites, precipitation monitoring sites, location of point sources, land use and soil properties. PC-based ArcView 3.2a (ESRI, 2000) was used to manage the GIS data layers. For each water quality monitoring site in both catchments, 
corresponding drainage areas were delineated based on the digital terrain model (DTM) using the data pre-processing tool of AVSWAT 2000 in ArcView (Di Luzio et al., 2002). In the Upper-Scheldt catchment, 67 watersheds were delineated with an area ranging between 1 and $109 \mathrm{~km}^{2}$. In the Nete catchment, 106 watersheds were delineated with an area ranging between 2 and $710 \mathrm{~km}^{2}$.

Precipitation data of the years 1998-2001 from 5 meteostations in the Upper-Scheldt catchment and 7 stations in the Nete catchment were obtained from the Royal Meteorological Institute. Thiessen polygons were created with the ArealRain extension in ArcView (Petras, 2001). The seasonal precipitation attributed to each watershed was derived from the Thiessen polygon showing the largest overlap with the considered watershed.

Discharge and nutrient concentration data of all point sources were obtained from the Flemish Environment Agency. Three types of point sources were used: (1) discharge of treated industrial wastewater in surface waters, (2) discharge of industrial wastewater in a sewer not yet connected to a wastewater treatment plant, and (3) discharge of treated sewage coming from a wastewater treatment plant. For each point source, mean yearly discharge and nitrate and phosphate concentrations were calculated, so that mean yearly loadings of nitrate and phosphate could be calculated by multiplying discharge with concentration. For each water quality monitoring site, loadings of all upstream point sources were summed according to the three different types of point source. Uptake and transformation processes were not taken into account.

GIS-derived morphological characteristics were watershed area, average watershed slope, drainage density and elongation. The digital terrain model (DTM) used to derive the average slope was interpolated from digital elevation data obtained from the National Geographic Institute. Calculation of the drainage density was based on the Flemish Hydrological Atlas (VHA), delivered by the Flemish Land Agency (VLM). The elongation of a watershed was defined as the ratio of the diameter of a circle with the same area as the watershed, to the watershed length (Langford and O'Shaughnessy, 1977, cited by Post and Jakeman, 1999). Digital land use maps were obtained from the Flemish Land Agency (VLM). Land use categories were aggregated into four classes: (1) agricultural land, including row and non-row crops, (2) pasture, (3) forests, and (4) urban land, including industrial and residential areas. Each land use class was expressed as a fraction of the total watershed area. Soil properties were derived from the digital soil maps created by the Flemish Land Agency (VLM). The VLM soil texture classes were aggregated into the following four classes: (1) loam (symbol A), (2) sand loam (symbol L), (3) loamy sand (symbols S and P), and (4) sand (symbol Z). The VLM soil drainage characteristics were also aggregated into four classes: (1) well drained (symbols a, b and B), (2) moderately drained (symbols c, d and D), (3) poorly drained (symbols e, f, g, F and G), and
(4) poorly drained with stagnating water (symbols h, i and I). Each soil texture and drainage class was expressed as a proportion of the total watershed area.

Finally, a proximity analysis was conducted by delineating buffer zones around the VHA-streams within each watershed. Zone widths of 100 and $250 \mathrm{~m}$ from VHA-streams were selected, after which land use, soil texture and soil drainage compositions of these buffer zones of all watersheds were calculated.

All calculated explanatory watershed characteristic variables are presented in Table 1.

\subsection{Statistical analyses}

Descriptive statistics were calculated for the watershed and water quality databases of both the Upper-Scheldt and Nete catchment (Table 2). Distributional properties of all variables were assessed and the Kolmogorov-Smirnov goodness of fit test was used to test for normality of distribution of the watershed and water quality variables. When necessary the dependent water quality variables were log transformed. Some of the explanatory watershed variables could not be normalised. To examine the degree of interdependence or multicollinearity within the explanatory watershed variables, non-parametric Spearman rank correlations were calculated.

Watershed characteristics and water quality interactions were examined using two techniques: (1) a non-parametric Spearman rank correlation analysis was applied to determine the direction and magnitude of the interaction between individual watershed characteristics and nitrate and phosphate concentrations, and (2) the relative importance of the watershed characteristics grouped per environmental theme (precipitation, point sources, morphological characteristics, land use, soil properties) was examined by partial regression analysis (Legendre and Legendre, 1998; Lichtstein et al., 2002, Deckers et al., 2004). With respect to the latter, the following procedure was adopted and repeated for both catchments. First, a multiple regression model was built with all explanatory variables. Next, a multiple regression model was built with all explanatory variables except those of the studied factor group. The unique contribution of the concerning factor group is then given by its partial $\mathrm{R}^{2}$, calculated as the difference in $\mathrm{R}^{2}$ between the full model, containing all variables, and the corresponding reduced model, lacking the variables of the concerning factor group. The strength of this method is that it explicitly accounts for the intrinsic existence of correlation between variables of different factor groups by partialling out shared components of variation explained by the various factor groups (Deckers et al., 2004). After calculating partial $\mathrm{R}^{2}$ for all seasons of the years 1998-2001, mean seasonal and overall mean partial $\mathrm{R}^{2}$ were calculated. Differences in partial $\mathrm{R}^{2}$ of all distinct factor groups were tested by the non-parametric Friedman test and the Dunn test (Siegel and Castellan, 1988). The question whether nutrient concentrations are primarily influenced by riparian zone or 
Table 1. Watershed characteristics used as independent variables.

\begin{tabular}{lll}
\hline Group & Variable & Unit \\
\hline Precipitation & Seasonal rainfall & $\mathrm{mm}$ in 3 months \\
Point sources & Treated industrial point source load in surface water & $\mathrm{g} \mathrm{N}$ or P/day \\
& Untreated industrial point source load in a sewer & $\mathrm{g} \mathrm{N}$ or P/day \\
& Point source load coming from a WTP & $\mathrm{g} \mathrm{N}$ or P/day \\
Morphology & Watershed area & $\mathrm{m}^{2}$ \\
& Mean basin slope & $\%$ \\
& Drainage density & $\mathrm{m} / \mathrm{ha}$ \\
\multirow{5}{*}{ Land use } & Elongation & $\mathrm{m} / \mathrm{m}$ \\
& Arable & $\%$ \\
& Pasture & $\%$ \\
& Forest & $\%$ \\
& Urban & $\%$ \\
& Loam & $\%$ \\
& Sandy loam & $\%$ \\
& Loamy sand & $\%$ \\
& Sand & $\%$ \\
& Well drained & $\%$ \\
& Moderately drained & $\%$ \\
& Poorly drained & $\%$ \\
& Poorly drained with stagnating water & $\%$ \\
\hline
\end{tabular}
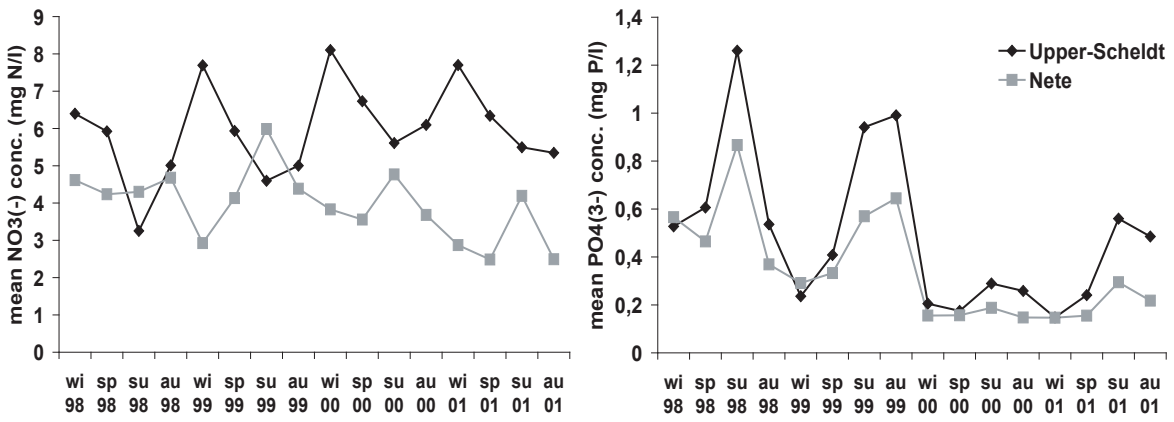

Fig. 2. Trends in mean seasonal nitrate and phosphate concentrations $($ wi $=$ winter, $s p=$ spring, $s u=$ summer, $a u=a u t u m n)$.

by whole-watershed characteristics was examined with partial regression, the Friedman test and the Dunn test. Watershed characteristics examined were land use, soil texture and soil drainage class. Factor groups consisted of whole watershed characteristics, characteristics within a 250 and a $100 \mathrm{~m}$-buffer.

\section{Results and discussion}

\subsection{Seasonal patterns}

Seasonal concentrations of nitrate and phosphate averaged for all sampling sites of the Upper-Scheldt and Nete catchments are presented in Fig. 2. Nutrient concentrations are highest in the Upper-Scheldt catchment. This is most likely due to the higher input of $\mathrm{N}$ and $\mathrm{P}$ fertilizer in the Upper-
Scheldt catchment, in which agriculture is a more dominant activity than in the Nete catchment (46\% versus $29 \%$ ).

The seasonal variation in nitrate concentration in the catchment of the Nete is opposite to the more commonly observed pattern of dormant season maxima and growing season minima as observed in the Upper-Scheldt catchment. High stream nitrate concentrations during the dormant season are thought to be the result of a reduced uptake by terrestrial vegetation and of increased leaching (Neill, 1989). When soils remain unfrozen during winter, rates of nitrogen immobilization associated with microbial decomposition of autumn-shed leaves may be high in soils and streams (Mulholland, 1992). Since the catchment of the Nete has more forests (30\% versus $8 \%$ ) and more poorly drained soils (23\% versus $7 \%$ ) than the Upper-Scheldt catchment conditions for denitrification might be more favourable in the Nete 
Table 2. Descriptive statistics $(\min =$ minimum, mean $=$ arithmetic mean, max $=$ maximum $)$ of the time-independent watershed characteristics in the whole catchments and the buffer strips of $250 \mathrm{~m}$ and $100 \mathrm{~m}$ of the Upper-Scheldt and Nete catchments.

\begin{tabular}{|c|c|c|c|c|c|c|c|}
\hline \multirow[t]{2}{*}{ Variable } & \multirow{2}{*}{$\begin{array}{l}\text { Spatial } \\
\text { extent }\end{array}$} & \multicolumn{3}{|c|}{ Upper-Scheldt } & \multicolumn{3}{|c|}{ Nete } \\
\hline & & $\min$ & mean & $\max$ & $\min$ & mean & $\max$ \\
\hline Watershed area & & 52.3 & 1509.6 & $10,930.4$ & 177.8 & 6651.3 & 71005.9 \\
\hline Mean basin slope & & 0 & 1.627 & 4.820 & 0.051 & 0.236 & 0.580 \\
\hline Drainage density & & 6.93 & 17.35 & 38.99 & 1.02 & 27.87 & 418.14 \\
\hline Elongation & & 0.49 & 0.76 & 1.17 & 0.34 & 0.63 & 1.09 \\
\hline \multirow[t]{3}{*}{ Arable } & whole & 0 & 14.3 & 51.1 & 0.2 & 20.9 & 50.8 \\
\hline & $250 \mathrm{~m}$ & 0 & 12.7 & 45.7 & 0.4 & 18.0 & 44.5 \\
\hline & $100 \mathrm{~m}$ & 0 & 10.7 & 45.3 & 0 & 15.5 & 51.5 \\
\hline \multirow[t]{3}{*}{ Pasture } & whole & 11.2 & 46.4 & 85.4 & 9.3 & 30.4 & 59.0 \\
\hline & $250 \mathrm{~m}$ & 13.5 & 45.3 & 85.6 & 7.2 & 35.2 & 60.6 \\
\hline & $100 \mathrm{~m}$ & 8.9 & 45.0 & 79.1 & 7.5 & 36.8 & 64.3 \\
\hline \multirow[t]{3}{*}{ Forest } & whole & 5.0 & 28.0 & 42.5 & 5.8 & 16.2 & 42.7 \\
\hline & $250 \mathrm{~m}$ & 0 & 28.2 & 55.7 & 2.3 & 17.6 & 52.2 \\
\hline & $100 \mathrm{~m}$ & 5.8 & 28.5 & 50.9 & 3.8 & 18.0 & 48.9 \\
\hline \multirow[t]{3}{*}{ Urban } & whole & 0 & 8.8 & 77.4 & 1.9 & 27.0 & 71.1 \\
\hline & $250 \mathrm{~m}$ & 0 & 10.9 & 77.2 & 0.9 & 25.0 & 62.1 \\
\hline & $100 \mathrm{~m}$ & 0 & 14.1 & 79.1 & 1.0 & 26.8 & 66.9 \\
\hline \multirow[t]{3}{*}{ Loam } & whole & 0 & 44.2 & 100.0 & 0 & 0 & 0 \\
\hline & $250 \mathrm{~m}$ & 0 & 43.6 & 100.0 & 0 & 0 & 0 \\
\hline & $100 \mathrm{~m}$ & 0 & 44.0 & 99.6 & 0 & 0 & 0 \\
\hline \multirow[t]{3}{*}{ Sandy loam } & whole & 0 & 28.5 & 97.1 & 0 & 3.8 & 78.7 \\
\hline & $250 \mathrm{~m}$ & 0 & 29.4 & 96.5 & 0 & 4.8 & 78.0 \\
\hline & $100 \mathrm{~m}$ & 0 & 29.0 & 98.6 & 0 & 5.8 & 79.9 \\
\hline \multirow[t]{3}{*}{ Loamy sand } & whole & 0 & 4.6 & 79.6 & 0 & 35.2 & 92.1 \\
\hline & $250 \mathrm{~m}$ & 0 & 4.1 & 78.0 & 0 & 42.6 & 95.7 \\
\hline & $100 \mathrm{~m}$ & 0 & 4.2 & 79.5 & 0 & 47.8 & 99.2 \\
\hline \multirow[t]{3}{*}{ Sand } & whole & 0 & 9.0 & 99.1 & 0 & 39.3 & 99.6 \\
\hline & $250 \mathrm{~m}$ & 0 & 8.9 & 97.8 & 0 & 36.2 & 99.1 \\
\hline & $100 \mathrm{~m}$ & 0 & 8.3 & 94.4 & 0 & 31.4 & 99.0 \\
\hline \multirow[t]{3}{*}{ Well drained } & whole & 0 & 29.4 & 76.0 & 0 & 9.0 & 50.1 \\
\hline & $250 \mathrm{~m}$ & 0 & 17.6 & 68.5 & 0 & 4.6 & 24.3 \\
\hline & $100 \mathrm{~m}$ & 0 & 10.1 & 63.9 & 0 & 2.5 & 21.5 \\
\hline \multirow[t]{3}{*}{ Moderately drained } & whole & 16.2 & 49.7 & 98.7 & 14.7 & 46.2 & 88.9 \\
\hline & $250 \mathrm{~m}$ & 17.9 & 56.7 & 98.5 & 14.7 & 44.5 & 87.0 \\
\hline & $100 \mathrm{~m}$ & 13.4 & 55.3 & 99.7 & 5.4 & 38.1 & 84.5 \\
\hline \multirow[t]{3}{*}{ Poorly drained } & whole & 0 & 6.5 & 21.4 & 0 & 20.8 & 55.8 \\
\hline & $250 \mathrm{~m}$ & 0 & 10.8 & 32.0 & 0 & 33.3 & 70.4 \\
\hline & $100 \mathrm{~m}$ & 0 & 19.5 & 54.8 & 0 & 43.3 & 85.6 \\
\hline \multirow[t]{3}{*}{ Stagnating water } & whole & 0 & 3.8 & 51.2 & 0 & 1.2 & 21.9 \\
\hline & $250 \mathrm{~m}$ & 0 & 5.2 & 55.1 & 0 & 1.6 & 35.1 \\
\hline & $100 \mathrm{~m}$ & 0 & 6.4 & 61.4 & 0 & 2.2 & 52.0 \\
\hline
\end{tabular}

catchment, which helps to explain why dormant season maxima are not outspoken.

The seasonal variation in phosphate concentration is similar in both catchments, showing peaks in summer. The same pattern was observed by Osborne and Wiley (1988). Higher concentrations during summer are likely the result of the less frequent occurrence of showers in the summer season and the less dilution of phosphate point sources due to the overall lower base flow in summer.
3.2 Linkages between watershed characteristics and nutrient concentrations

\subsubsection{Nitrate}

In both the Nete and Upper-Scheldt catchment, the explanative value of the different watershed characteristics differs significantly (Table 3 ). Soil drainage and soil texture predict stream nitrate concentrations significantly better than 
Table 3. Results of Friedman test to compare partial $\mathrm{R}^{2}$ of the different groups of watershed characteristics in explaining nutrient concentrations at the mouth.

\begin{tabular}{lcccc}
\hline & \multicolumn{2}{c}{ Nitrate } & \multicolumn{2}{c}{ Phosphate } \\
& Upper-Scheldt & Nete & Upper-Scheldt & Nete \\
\hline Chi-square & 18.607 & 64.517 & 25.923 & 25.923 \\
$\mathrm{~N}$ & 16 & 16 & 16 & 16 \\
$\mathrm{Df}$ & 5 & 5 & 5 & 5 \\
Asymptotic significance & 0.002 & 0.000 & 0.000 & 0.000 \\
\hline
\end{tabular}

Table 4. Mean Spearman rank correlation coefficients between watershed characteristics and water quality for all seasons of 1998-2001 [between brackets the frequency of significant correlation out of 16 (4 years with 4 seasons)].

\begin{tabular}{lcccc}
\hline & \multicolumn{2}{c}{ Nitrate } & \multicolumn{2}{c}{ Phosphate } \\
& Upper-Scheldt & Nete & Upper-Scheldt & Nete \\
\hline Seasonal rainfall & $-0.304(7)$ & $0.031(0)$ & $0.005(0)$ & $-0.045(1)$ \\
Treated Industrial & $-0.154(2)$ & $-0.039(1)$ & $0.389(9)$ & $-0.178(8)$ \\
Untreated Industrial & $-0.168(0)$ & $0.117(0)$ & $0.449(12)$ & $0.240(10)$ \\
WTP & $-0.017(0)$ & $0.321(12)$ & $-0.139(0)$ & $0.043(0)$ \\
Watershed area & $-0.168(2)$ & $-0.109(5)$ & $0.215(2)$ & $-0.177(8)$ \\
Mean basin slope & $0.191(5)$ & $-0.133(3)$ & $-0,481(11)$ & $-0.154(4)$ \\
Stream density & $0.121(1)$ & $0.016(0)$ & $-0.398(9)$ & $-0.024(0)$ \\
Elongation & $-0.034(0)$ & $0.284(12)$ & $-0.155(1)$ & $0.253(8)$ \\
Arable & $0.518(13)$ & $-0.053(0)$ & $0.004(0)$ & $-0.065(2)$ \\
Pasture & $0.012(0)$ & $0.150(5)$ & $-0.178(3)$ & $0.156(5)$ \\
Forest & $-0.329(10)$ & $0.022(0)$ & $-0.014(0)$ & $-0.279(9)$ \\
Urban & $-0.500(13)$ & $0.037(0)$ & $0.306(7)$ & $0.320(12)$ \\
Loam & $0.117(0)$ & - & $-0.241(4)$ & - \\
Sandy loam & $0.141(4)$ & $-0.023(2)$ & $0.158(0)$ & $0.158(2)$ \\
Loamy sand & $-0.200(2)$ & $-0.165(5)$ & $0.339(5)$ & $0.097(1)$ \\
Sand & $-0.148(7)$ & $0.131(3)$ & $-0.063(1)$ & $-0.281(10)$ \\
Well drained & $0.538(13)$ & $-0.445(16)$ & $-0.202(2)$ & $-0.349(11)$ \\
Moderately drained & $-0.279(6)$ & $0.171(5)$ & $-0.063(0)$ & $0.236(9)$ \\
Poorly drained & $-0.365(7)$ & $-0.126(2)$ & $0.131(1)$ & $-0.217(9)$ \\
Stagnating water & $-0.048(1)$ & $0.260(11)$ & $0.209(3)$ & $0.134(5)$ \\
\hline
\end{tabular}

precipitation in both catchments (Fig. 3). In the Nete catchment the watershed morphology and point sources also play a more significant role than precipitation. The reason for the observed low influence of precipitation on nutrient concentrations must be sought in the spatial and temporal limitations of both precipitation and water quality data: precipitation data are spatially limited while monthly water quality data in the absence of discharge data are subject to fluctuations which could not be taken into account. Therefore, the further analysis was concentrated on the non-time-dependent variables.

In the Upper-Scheldt catchment soil drainage explains better the observed variability in nitrate concentrations than point sources (Fig. 3). Though, when only the summer season is taken into account, point sources have the largest partial $\mathrm{R}^{2}$ of all factor groups (data not shown). A likely explanation is that in summer (1) biomass production and plant $\mathrm{N}$ uptake peak and rainfall excess is small resulting in no or very small leaching of nitrate and (2) effluents of point sources are less diluted due to the overall lower base flow (Osborne and Wiley, 1988). A strong positive correlation exists between the proportion of well drained soils and downstream nitrate concentrations (Table 4). This can be explained by the higher infiltration capacity, the shorter residence time of subsurface water and groundwater and consequently less denitrification taking place (Mueller et al., 1997). Furthermore, a strong positive correlation is observed between the area of agricultural land and downstream nitrate concentrations, a pattern observed in many other studies (Hill, 1978; Neill, 1989; Johnson et al., 1997; Tufford et al., 1998). The observed negative correlation between the proportion of forest and downstream nitrate concentrations 

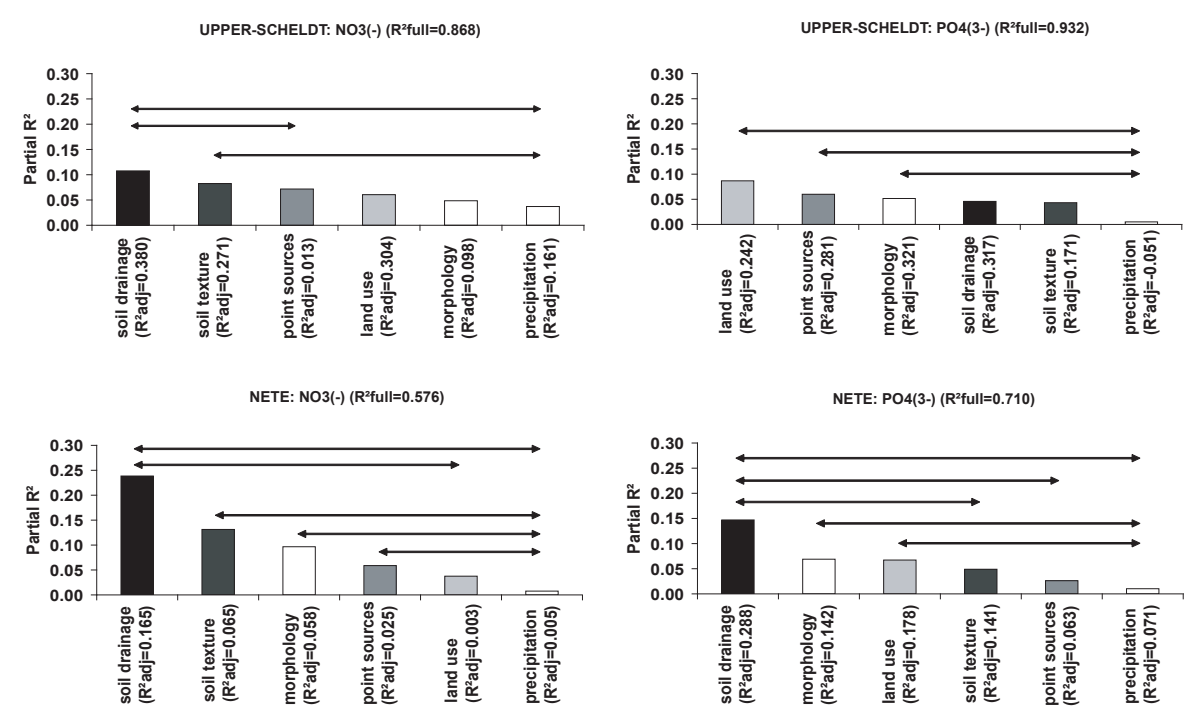

Fig. 3. Mean partial $R^{2}$ for all seasons of 1998-2001 (arrows indicate significantly different factor groups). Mean adjusted $R^{2}$ for each of the factor groups and mean $\mathrm{R}^{2}$ of the full model are given between brackets.

is in agreement with the results of Hunsaker and Levine (1995), but the negative correlation between the proportion of urban land and downstream concentrations contrasts to other reports (Osborne and Wiley, 1988; Sliva and Williams, 2001; Davies \& Neal, 2004) and may according to Tufford et al. (1998) be the result of multicollinearity.

In the Nete catchment, soil drainage accounts better for the observed variability in nitrate concentrations than land use (Fig. 3). This is in agreement with the conclusion of Norton and Fisher (2000) that soil characteristics can completely over-ride land use effects. The strong negative correlation between the proportion of well drained soils and downstream nitrate concentrations (Table 4) is somehow contradictory, unless the plant uptake of $\mathrm{N}$ in well drained soils is considerably higher than in poorly drained soils. Other Spearman rank correlations in the Nete catchment show that nitrate loadings coming from wastewater treatment plants (WTP's) go hand in hand with higher downstream nitrate concentrations (Table 4) indicating that nitrate removal by WTP's is highly insufficient. In the Upper-Scheldt catchment, the inefficiency of nitrate removal by wastewater treatment infrastructure was not detected because the low number of WTP's. Furthermore, the watershed elongation of the Nete catchment is positively correlated to downstream nitrate concentrations (Table 4) suggesting that lower nitrate concentrations are observed downstream of lengthened watersheds, which can be explained by the longer residence time enhancing natural decay processes.

\subsubsection{Phosphate}

As for nitrate, the explanative value of the different themes of watershed characteristics is significantly different in both the Upper-Scheldt and Nete catchment (Table 3). The influence of precipitation is again negligible, for the same reason as stated before, and is not taken into account in the further analysis.

In the Upper-Scheldt catchment no significant difference could be detected between the different watershed characteristics (Fig. 3). The Spearman rank correlations revealed that industrial point sources are positively correlated to downstream phosphate concentrations (Table 4). Furthermore, a negative correlation exists between the morphological characteristics mean slope and stream density of the watershed and phosphate concentrations, whereas one would expect the opposite, i.e. the steeper the mean catchment slope the more likely overland flow and transport of soil particles will occur, and the more easy sediments loaded with phosphate reach the drainage network. No direct explanation for the negative correlation could be found.

In the Nete catchment, soil drainage accounts better for the observed variation in phosphate concentration than point source loadings and proportions of soil texture classes (Fig. 3). The proportion of urban land is positively correlated with downstream phosphorus concentrations (Table 4). This relationship may be highly influenced by point sources as well as diffuse sources. From the different types of point sources, discharge of treated industrial wastewater in a sewer not connected to a WTP is most important (Table 4). This is in agreement with the statement of Sonzogni et al. (1980) that highly industrialized urban areas contribute more phosphorus per unit area than residential areas. Diffuse source 
Table 5. Results of Friedman test to compare partial $\mathrm{R}^{2}$ of land use and soil characteristics within different distances of the streams in explaining nutrient concentrations at the mouth.

\begin{tabular}{llcccc}
\hline & & \multicolumn{2}{c}{ Nitrate } & \multicolumn{2}{c}{ Phosphate } \\
& & Upper-Scheldt & Nete & Upper-Scheldt & Nete \\
\hline Land use & Chi-square & 13.333 & 3.270 & 9.125 & 2.952 \\
& N & 16 & 16 & 16 & 16 \\
& Df & 2 & 2 & 2 & 2 \\
& Asymptotic significance & 0.001 & 0.195 & 0.010 & 0.229 \\
& Chi-square & 1.238 & 9.375 & 6.097 & 6.125 \\
& N & 16 & 16 & 16 & 16 \\
& Df & 2 & 2 & 2 & 2 \\
& Asymptotic significance & 0.538 & 0.009 & 0.047 & 0.047 \\
& Chi-square & 7.125 & 8.000 & 14.400 & 1.625 \\
& N & 16 & 16 & 16 & 16 \\
& Df & 2 & 2 & 2 & 2 \\
& Asymptotic significance & 0.028 & 0.018 & 0.001 & 0.444 \\
\hline
\end{tabular}

pollution in urban areas is caused by artificial sealing of the surface resulting in more runoff (Sonzogni et al., 1980; Field et al., 1996) and less pollutant attenuation (Soranno et al., 1996; Corbett et al., 1997). From Table 4 it is also clear that a negative correlation exists between the proportion of sandy soils and downstream phosphorus concentrations. Greater amounts of sandy soils result in greater infiltration and thus, less potential soil erosion and overland transport of phosphorus (Norton and Fisher, 2000). This effect is accentuated because the soils are sandy and covered by forests, having a positive impact on water quality in a number of ways: (1) sandy soils act as effective sediment traps, (2) forests consume and store nutrients, and (3) rhizosphere of forests stimulate microbial assimilation of nutrients (Norton and Fisher, 2000).

\subsection{Buffer strip versus whole-catchment characteristics}

Results of the partial regression analysis to examine the relative influence of buffer strip versus whole catchment land use and soil characterics on nutrient concentrations are presented in Table 5 and Fig. 4. Neither in the Nete nor in the Upper-Scheldt catchment, land use close to the stream channel $(<100$ or $<250 \mathrm{~m})$ is a better predictor of nitrate or phosphate concentrations than land use away from the channel ( $>100$ or $>250 \mathrm{~m}$ ) (Fig. 4). Probably, the mediating impact of riparian zones is not primarily dependent on land use activities. Rather, the hydrologic pathways within the buffer strip play a more important role. Both soil properties (texture and drainage) in the riparian zone of the Nete catchment have a higher explanative value to downstream nitrate concentrations than these properties for the whole watershed (Fig. 4). In the Nete catchment, where soils are dominantly moderately drained sands, a higher proportion of poorly drained loamy sands in the riparian zone lead to lower nitrate concentrations (Table 4). Probably, these soils retard the move- ment of subsurface flow increasing the time for denitrification to take place. Moreover, waterlogged conditions promote the denitrification process. The difference in partial $\mathrm{R}^{2}$ is most distinct in spring (data not shown), simultaneously with the lowest observed nitrate concentrations (Fig. 2). A plausible explanation is that the sum of denitrification and $\mathrm{N}$ uptake are highest in spring, whereas in winter $\mathrm{N}$ uptake ceases close to zero and denitrification reaches its maximum value, and in summer $\mathrm{N}$ uptake is maximal while denitrification hardly occurs. Although the proportion of agricultural land increases simultaneously with an increase in fine textured soils (loamy sands) within the riparian zones, land use within the riparian zone is not a better predictor of nitrate concentrations than land use in the whole watershed. In the Upper-Scheldt catchment, no significant difference in explanative value of soil properties is observed between the buffers and the whole catchment when nitrate concentrations are considered. Phosphate concentrations, though, are better predicted by soil drainage characteristics in the riparian zone. Soil drainage characteristics in the riparian zone influence erosion through soil infiltration capacity (Norton and Fisher, 2000).

\section{Conclusions}

The analysis of the influence of a set of watershed characteristics categorised in environmental themes (precipitation, point sources, morphological characteristics, land use, soil properties) on instream nutrient concentrations in the River Scheldt Basin suggests that instream nutrient concentrations are largely regulated by soil drainage characteristics of the watershed. Additional influence is exerted by anthropogenic land use and point source loading variables. Despite the well-known difficulties in separating the influence of a set of intercorrelated watershed characteristics, the unique 
UPPER-SCHELDT: NO3(-)

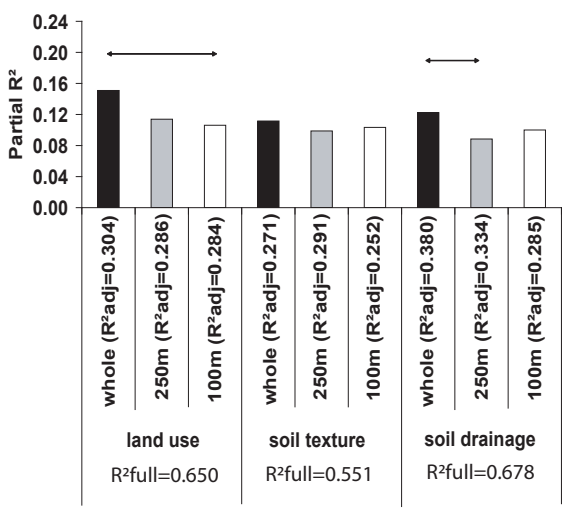

NETE: NO3(-)

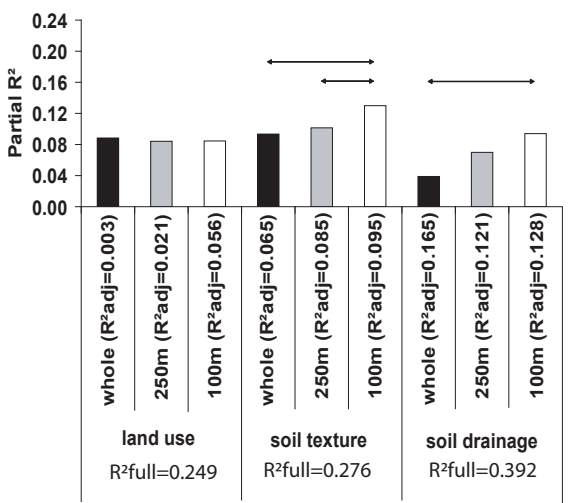

UPPER-SCHELDT: PO4(3-)

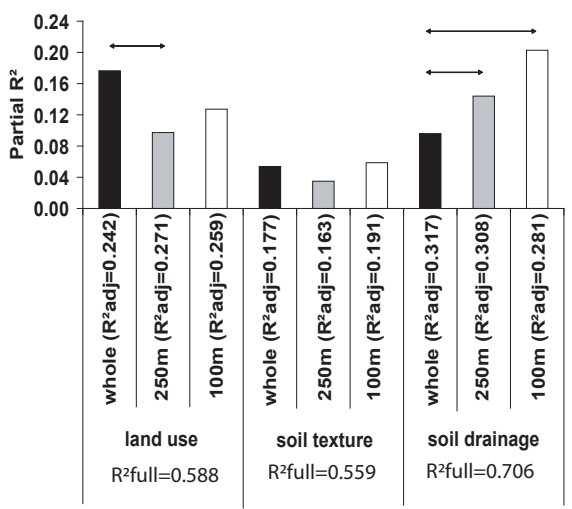

NETE: PO4(3-)

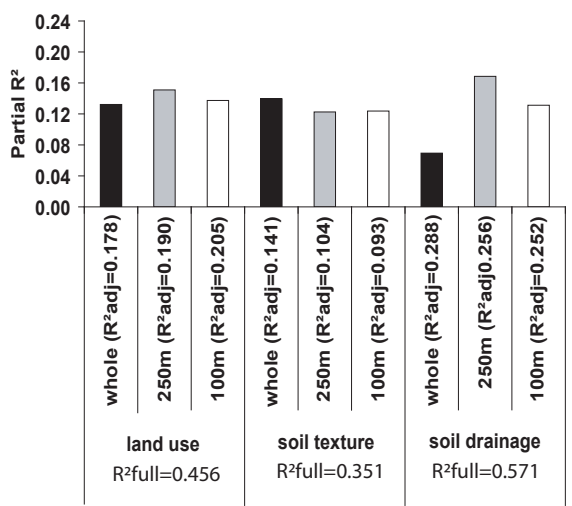

Fig. 4. Mean partial $R^{2}$ for all seasons of 1998-2001 (arrows indicate significantly different factor groups). Mean adjusted $R^{2}$ for each of the factor groups and mean $\mathrm{R}^{2}$ of the full model are added.

contribution of each theme of watershed characteristics could be calculated using partial regression analysis. The data from the River Scheldt Basin suggest that an understanding of diffuse source contributions to observed instream nutrient concentrations cannot be based solely on an examination of land use variables. Such an approach may frequently provide a misleading impression of the significance of human activities. The same conclusion could be drawn from the proximity analysis. Land use close to the river was not a better predictor of nitrate and phosphate concentrations than land use away from the river. The mediating impact of riparian zones is rather explained by the hydrologic pathways within the buffer strip. Further investigations which make use of a better designed spatial and temporal sampling regime as well as a higher resolution of digital maps are required to evaluate the complex interactions which are responsible for variations in watershed nutrient exports and instream nutrient concentrations.

Edited by: A. D. Reeves

\section{References}

Basnyat, P., Teeter, L. D., Flynn, K. M., and Lockaby, B.G.: Relationships between landscape characteristics and nonpoint source pollution inputs to coastal estuaries, Environ. Manage., 23, 539549, 1999.

Bolstad, P. V. and Swank, W. T.: Cumulative impacts of landuse on water quality in a southern Appalachian watershed, J. - Am. Water Resour. Assoc., 33, 519-533, 1997.

Bormann, F. H., Likens, G. E., and Eaton, J. S.: Biotic regulation of particulate and solution losses from a forest ecosystem, BioScience, 19, 600-610, 1969.

Corbett, C. W., Wahl, M., Porter, D. E., Edwards, D., and Moise, C.: Nonpoint source runoff modeling A comparison of a forested and an urban watershed on the South Carolina coast, J. Exp. Mar. Biol. Ecol., 213, 133-149, 1997.

Davies, H. and Neal, C.: GIS-based methodologies for assessing nitrate, nitrite and ammonium distributions across a major UK basin, the Humber, Hydrol. Earth Syst. Sci., 8, 823-833, 2004, http://www.hydrol-earth-syst-sci.net/8/823/2004/.

Deckers, B., Hermy, M., and Muys, B.: Factors affecting plant species composition of hedgerows Relative importance and hierarchy, Acta Oecologica, 26, 23-37, 2004.

Dillaha, T. A., Sherrard, J. H., and Lee, D.: Long-term effectiveness 
of vegetative filter strips, Water Environ. Technol., November, 419-421, 1989.

Di Luzio, M., Srinivasan, R., Arnold, J. G., and Neitsch, S. L.: Soil and Water Assessment Tool ArcView GIS Interface Manual Version 2000, Texas Water Resources Institute, Texas, 2002.

Dzikiewicz, P.: Activities in nonpoint pollution control in rural areas of Poland, Ecol. Eng., 14, 429-434, 2000.

ESRI: ArcView 3.2a, Environmental systems Research Institute Inc., Redlands CA, 2000.

Fennessy, M. S. and Cronk, J. K.: The effectiveness and restoration potential of riparian ecotones for the management of nonpoint source pollution, particularly nitrate, Critical Reviews in Environmental Science and Technology, 27, 285-317, 1997.

Field, C. K., Siver, P. A., and Lott, A.: Estimating the effects of changing land use patterns on Connecticut Lakes, J. Environ. Qual., 25, 325-333, 1996.

Haag, D. and Kaupenjohann, M.: Landscape fate of nitrate fluxes and emissions in Central Europe A critical review of concepts, data, and models for transport and retention, Agriculture, Ecosyst. Environ., 86, 1-21, 2001.

Haycock, N. E., Pinay, G., and Walker, C.: Nitrogen retention in river corridors European perspective, Ambio, 22, 340-346, 1993.

Heathwaite, A. L., Johnes, P. J., and Peters, N. E.: Trends in nutrients, Hydrol. Processes, 10, 263-293, 1996.

Hill, A. R.: Factors affecting the export of nitrate-nitrogen from drainage basins in southern Ontario, Water Res., 12, 1045-1057, 1978.

Hill, A. R.: Nitrate removal in stream riparian zones, J. Environ. Qual., 25, 743-755, 1996.

Hunsaker, C. T. and Levine, D. A.: Hierarchical approaches to the study of water quality in rivers. Spatial scale and terrestrial processes are important in developing models to translate research results to management practices, BioScience, 45, 193-203, 1995.

Johnson, L. B., Richards, C., Host, G. E., and Arthur, J. W.: Landscape influences on water chemistry in Midwestern stream ecosystems, Freshwater Biol., 37, 193-208, 1997.

Legendre, P. and Legendre, L.: Numerical Ecology, Elsevier Science, Amsterdam, 1998.

Lichtstein, J. W., Simons, T. R., and Fransreb, K. E.: Landscape effects on breeding songbird abundance in managed forests, Ecol. Appl., 12, 836-857, 2002.

Lowrance, R. R., Todd, R. L., Fail, J., Hendrickson, O., Leonard, R., and Asmussen, L. E.: Riparian forests as nutrient filters in agricultural watersheds, BioScience, 34, 374-377, 1984.

Mueller, D. K., Ruddy, B. C., and Battaglin, W. A.: Logistic model of nitrate in streams of the upper-midwestern United States, J. Environ. Qual., 26, 1223-1230, 1997.

Mulholland, P. J.: Regulation of nutrient concentrations in a temperate forest stream: roles of upland, riparian, and instream processes, Limnol. Oceanogr., 37, 1512-1526, 1992.

Neill, M.: Nitrate concentrations in river waters in the south-east of Ireland and their relationship with agricultural practice, Water Res., 23, 1339-1355, 1989.

Nikolaidis, N. P., Heng, H., Semagin, R., and Clausen, J. C.: Nonlinear response of a mixed land use watershed to nitrogen loading, Agric., Ecosyst. Environ.t, 67, 251-265, 1998.
Norton, M. M. and Fisher, T. R.: The effects of forest on stream water quality in two coastal plain watersheds of the Chesapeake Bay, Ecol. Eng., 14, 337-362, 2000.

Omernik, J. M., Abernathy, A. R., and Male, L. M.: Stream nutrient levels and proximity of agricultural and forest land to streams: some relationships, J. Soil Water Conservation, 36, 227-231, 1981.

Ometo, J. P., Marinelli, L., Ballester, M. V., Gessner, A., Krusche, A., Victoria, R., and Williams, M.: Effects of land use on water chemistry and macroinvertebrates in two streams of the Piracicaba river basin, south-east Brazil, Freshwater Biol., 44, 327 337, 2000.

Osborne, L. L. and Kovacic, D. A.: Riparian vegetated buffer strips in water-quality restoration and stream management, Freshwater Biology, 29, 243-258, 1993.

Osborne, L. L. and Wiley, M. J.: Empirical relationships between land use/cover and stream water quality in an agricultural watershed, J. Environ. Manage., 26, 9-27, 1988.

Peterjohn, W. T. and Correll, D. L.: Nutrient dynamics in an agricultural watershed: observations on the role of a riparian forest, Ecology, 65, 1466-1475, 1984.

Petras, I.: ArealRain.avx Areal Precipitation Calculation using Thiessen Polygons, AS11813.zip, 2001.

Pionke, H. B., Gburek, W. J., and Sharpley, A. N.: Critical source area controls on water quality in an agricultural watershed located in the Chesapeake Bay, Ecol. Eng., 14, 325-335, 2000.

Post, D. A. and Jakeman, A. J.: Predicting the daily streamflow of ungauged catchments in S.E. Australia by regionalising the parameters of a lumped conceptual rainfall-runoff model, Ecol. Modell., 123, 91-104, 1999.

Richards, C., Johnson, L. B., and Host, G. E.: Landscape-scale influences on stream habitats and biota, Can. J. Fisheries Aquatic Sci., 53 (suppl. 1), 295-311, 1996.

Siegel, S. and Castellan, N. J.: Nonparametric statistics for the behavioral sciences, McGraw-Hill, New York, 1988.

Sliva, L. and Williams, D.: Buffer zone versus whole catchment approaches to studying land use impact on river water quality, Water Res., 35, 3462-3472, 2001.

Sonzogni, W. C., Chesters, G., Coote, D. R., Jeffs, D. N., Konrad, J. C., Ostry, R. C., and Robinson, J. B.: Pollution from land runoff, Environ. Sci. Technol., 14, 148-153, 1980.

Soranno, P. A., Hubler, S. L., and Carpenter, S. R.: Phosphorus loads to surface waters: a simple model to account for spatial pattern of land use, Ecol. Appl., 6, 865-878, 1996.

Tufford, D. L., McKellar, H. N., and Hussey J. R.: In-stream nonpoint source nutrient prediction with land-use proximity and seasonality, J. Environ. Qual., 27, 100-111, 1998.

VMM: Waterkwaliteit - lozingen in het water 2001, Vlaamse Milieumaatschappij, Erembodegem, 2002.

Wilkin, D. C. and Jackson, R. W.: Nonpoint water quality contributions from land use, J. Environ. Syst., 13, 127-136, 1983. 